\title{
Reaction Behaviors of Mixed Burdens Consisting of Pellets and Sintered Ores in an Experimental Blast Furnace
} \author{
Peter SIKSTRÖM ${ }^{3)}$ \\ 1) Process Research Laboratories, Nippon Steel Corporation \\ 2) Raw Materials Division -II, Nippon Steel Corporation \\ 3) Luossavaara-Kiirunavaara AB (LKAB)
}

Kenichi Higuchi ${ }^{1)^{*}}$, Tsunehisa Nishimura ${ }^{1)}$, Tetsuya ShiodA $^{2)}$, Mikael Pettersson ${ }^{3)}$ and

Abstract: Low-MgO sintered ores have developed into dominant burden materials for large blast furnaces operating under high pulverized coal injection in Japan, because of their low gangue content and high strength. Mixing MgO-bearing burdens with low-MgO sintered ores is an effective approach to satisfy the $\mathrm{MgO}$ requirement of blast furnaces. Therefore, a basket-evaluation test was performed in an experimental blast furnace $(\mathrm{EBF})$ to investigate the reduction behavior of olivine pellets mixed with low-MgO sintered ores. The reduction behavior with lime-fluxed pellets was also evaluated as a reference. Softening-melting tests were also conducted under the same mixing conditions as those in the EBF tests. Olivine pellets exhibited smaller pores and contained finer hematite grains before reduction. These microstructural features influenced their reduction behavior, with low size disintegration observed in the lumpy zone in the EBF. Numerous cohesive masses with slag formed at the interface between sintered ores and lime-fluxed pellets in the EBF, facilitating their melting. In contrast, a small amount of slag was found at the interface between sintered ores and olivine pellets. The results of the softening-melting tests also revealed the superiority of olivine pellets during melting. Despite the low temperature of the initial melt formation during reduction, olivine pellets exhibited lower liquid ratios at high temperatures, resulting in a decrease in exuded slag when mixed with low-MgO sintered ores. This work proposes a general mechanism for the melting behaviors of mixed burden materials for blast furnaces.

Keywords: ironmaking; experimental blast furnace; olivine pellets; reduction; softening-melting; mixed burden; microstructure; cohesive zone; dissection.

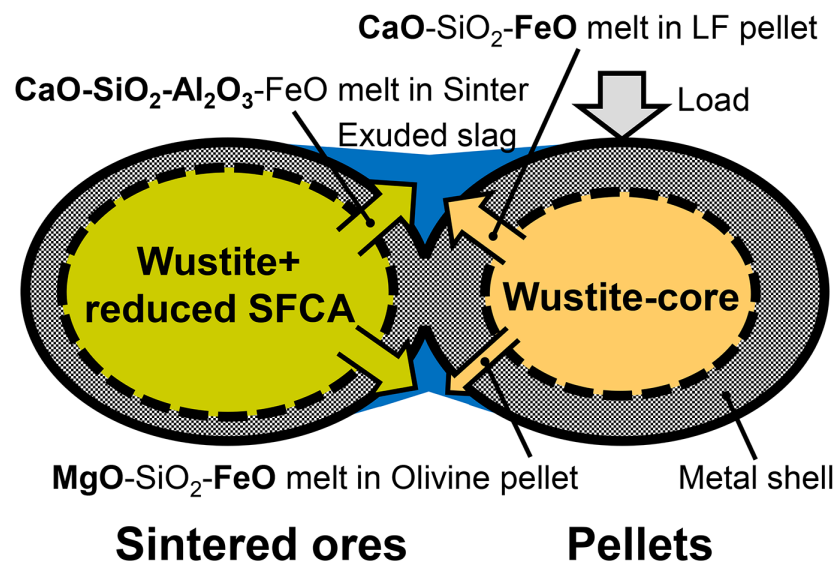

Received on Nov. 25, 2020 ; Accepted on Jan. 19, 2021 ; originally published in ISIJ Int., Vol.60 (2020), No.11, pp.2392-2399

* Corresponding author. E-mail: higuchi.t9g.kenichi@jp.nipponsteel.com, Address: Nippon Steel Corpration, 20-1 Shintomi Futtsu Chiba 293-8511 


\title{
試験高炉における焼結鉱とペレットの混合原料の反応挙動
}

\author{
樋口 謙一 ${ }^{1) *} \cdot$ 西村 恒久 ${ }^{1)} \cdot$ 塩田 哲也 ${ }^{2)} \cdot$ Mikael Pettersson $^{3)} \cdot$ Peter Sikstriöm $^{3)}$
}

Reaction Behaviors of Mixed Burdens Consisting of Pellets and Sintered Ores in an Experimental Blast Furnace

Kenichi Higuchi, Tsunehisa Nishimura, Tetsuya Shioda, Mikael Pettersson and Peter Sikström

\section{1. 緒言}

我が国では，高炉の高微粉炭比操業への移行に伴って， 炉内通気性を改善する低スラグ焼結鉱の製造が志向され てきた。一方で, 大型高炉のシャフト部の通気性確保のた めに, 焼結鉱の強度も求められている。そこで, $\mathrm{MgO}$ を 1.2 $\mathrm{wt} \%$ 以下まで低減した, 低 $\mathrm{MgO}$ 焼結鉱 ${ }^{1)}$ が主流となり, 現 在国内では8割の高炉が低 $\mathrm{MgO}$ 焼結鉱を使用している。し かし $\mathrm{MgO}$ は, 高炉スラグの流動性確保とスラグ外販時の 成分設計上，必要な成分である。現状は，塊状の $\mathrm{MgO}$ 副原 料が主に使用されているが，オリビンペレットのような $\mathrm{MgO}$ を含有する鉄原料の活用も有効である。

オリビンペレットの高炉内還元挙動の優劣は, 焼結鉱 と酸性ペレットの中間に位置する ${ }^{2-4)}$ 。MgOを含有するぺ レットの比較では, オリビンペレットはドロマイトペレッ トよりは劣ると報告されている ${ }^{5,6)}$ 。しかし，これらの評価 の多くは, 単味使用時のものである。混合使用時の還元挙 動に関する知見の方が，実機の高炉操業を考える上では 重要である。混合使用に関して, 異種ペレットの混合時 ${ }^{6,7)}$ や，塊鉱石と焼結鉱の混合時 ${ }^{8}$ の反応挙動が詳細に検討さ れている。しかし，我が国の主要な高炉原料である焼結鉱 に, ペレットを混合した際の混合挙動に関する知見は限定 される ${ }^{9,10)}$ 。特に，1999年から我が国の主流となっている 低 $\mathrm{MgO}$ 焼結鉱とオリビンペレットの混合時の評価に関す る知見は少ない。多くの報告で, 混合による軟化融着挙動 への相互作用が指摘されている。その機構は, 物理的な充 填構造変化と, 化学的な拡散打よび液相組成変化に大別さ れるが ${ }^{8)}$, 軟化融着挙動への影響が大きい $\mathrm{MgO}$ や塩基度に 大きな傾斜がある場合の相互作用は不明である。低 $\mathrm{MgO}$. 高塩基度の焼結鉱と，高 $\mathrm{MgO}$ ・低塩基度のペレットの組み 合わせは，均一化する過程での液相組成に大きな変化をも たらして, 軟化融着挙動が改善される可能性がある。
また近年, 試験高炉 (EBF) を用いた高炉の操業評価が 鋭意進められている。その結果の一部として, 装入物の融 着開始温度が, EBF内の融着帯の位置に対応し, 操業に影 響を与えると報告されている ${ }^{11)}$ 。らに, バスケット評価 試験により，装入物の炉内挙動の詳細が得られている ${ }^{12) 。 ~}$ この評価は, $\mathrm{EBF} の$ 急冷前に評価対象試料を封入したバス ケットを投入し，冷却後に採取して行われる。

そこで, 低 $\mathrm{MgO}$ 焼結鉱と数種のペレットの混合試料か らなる試料のバスケットを作成し，バスケット評価試験 で，これらの高炉内での還元挙動を調査した。さらに，同 一装入条件での荷重軟化試験も実施し, 異種原料混合時の 高炉内融着挙動を考察した。

\section{2. 試験方法}

\section{$2 \cdot 1$ 試験高炉による解析}

LKAB 社 (Luossavaara-Liirunavaara AB) の EBF (内容積 8.2 $\mathrm{m}^{3}$ ) を用いた。EBFの急冷前は, オリビンペレット $100 \%$ 操 業を3日間実施した。その操業は安定しており, RAR 560 $\mathrm{kg} / \mathrm{t}-\mathrm{HM}, \mathrm{PC}$ 比 $130 \mathrm{~kg} / \mathrm{t}-\mathrm{HM}$, 生産率 $1.55 \mathrm{~kg} / \mathrm{h}$ であった。試 駼操業の終了直前に, 試料を装入したバスケット 10 式を炉 頂から装入し，2週間冷却後に炉内から採取した。試料は， 3 種の高炉原料 (低 $\mathrm{MgO}$ 焼結鉱, Lime-fluxed ペレット (LF ペレット),オリビンペレット)を用いた。いずれも実機で 製造されたものであり, 焼結鉱は 10-15 mmに, ペレットは 10-12.5 mmに，それぞれ整粒したものを用いた。バスケッ 卜は金網製であり, 直径 $65 \mathrm{~mm}$, 長さ $200 \mathrm{~mm}$ のもを3個 直列に連結して一式とした。なお，バスケットによる内部 試料の保護効果が想定されるが，試料間の相対的な比較は 可能と考えた。3つのバスケットには，それぞれ $650 \mathrm{~g}$ の， (A) 焼結鉱 100\%，(B) 焼結鉱 50\%+ LFペレット $50 \%$ ，(C) 焼結鉱 $50 \%$ +オリビンペレット $50 \%$ ，を封入した。2 種原

原著論文 : ISIJ Int., Vol.60 (2020), No.11, pp. 2392-2399

2020年11月25日受付 2021年1月19日受理（Received on Nov. 25, 2020 ; Accepted on Jan. 19, 2021 ; originally published in ISIJ Int., Vol.60, 2020, No.11, pp. 23922399)

1）日本製鉄 (株) プロセス研究所 (Process Research Laboratories, Nippon Steel Corporation)

2) 日本製鉄 (株) 原料第二部 (Raw Materials Division - II, Nippon Steel Corporation)

3) Luossavaara-Kiirunavaara $\mathrm{AB}$ (LKAB)

* Corresponding author. E-mail : higuchi.t9g.kenichi@jp.nipponsteel.com, Address: Nippon Steel Corpration, 20-1 Shintomi Futtsu Chiba 293-8511 
料が混合されるバスケット（B, C) は，均一となるように封 入した。それぞれで $\mathrm{CaO} / \mathrm{SiO}_{2}$ と $\mathrm{MgO} / \mathrm{SiO}_{2}$ が異なるが, 基礎 的知見を得るために成分調整をせずに評価した。

還元前の焼結鉱とペレットの気孔率を, 2 種の方法 (2 $\mathrm{mm}$ 以下の気孔率 (水法, JIS K2151) と全気孔率 (表面の入 り江を含む $\left.{ }^{13}\right)$ ) で測定した。さらに，2.8-6.3 mmに粉砕し た試料を用いて, 水銀圧入ポロシメータで $200 \mu \mathrm{m}$ 以下の 気孔量と気孔径分布を測定した。さらに, 光学顕微鏡によ る組織観察を実施した。EBFのバスケット内から得られた 試料は，外観で焼結鉱，ペレット，融着物に選別後，それ ぞれの粒度分布，圧壊強度 (12 粒の平均值)，還元率， $<10$ $\mu \mathrm{m}$ 気孔量を測定し, 組織を観察した。

\section{$2 \cdot 2$ 荷重軟化試験}

EBFでのバスケット評価結果の検証として, 小型荷重軟 化試験装置 ${ }^{14)}$ を用いて, 混合原料の還元挙動を解析した。 10-12.5 mmに整粒後の試料を，120 g 用いた。試料は，黒鉛 坩堝内に, 粒径 9-13 mmのコークス層間に設置した。試料 の還元条件を, Fig.1に示す。加熱中の排ガス組成, 試料高 さ，圧損を測定した。

$\mathrm{T}_{\mathrm{S}}$ (圧損が $1.0 \mathrm{kPa}$ に達する時の温度), $\mathrm{T}_{\mathrm{E}}$ (圧損が上昇後 $1.0 \mathrm{kPa}$ 以下となる時の温度)， $\mathrm{T}_{50}$ (収縮率が $50 \%$ に達する 温度), $\mathrm{T}_{\mathrm{D}}$ (最初の滴下を検知した温度), $\mathrm{dT}\left(\mathrm{T}_{\mathrm{E}}-\mathrm{T}_{\mathrm{S}}\right), \mathrm{S}$ 值 (圧損の温度積分値), $\mathrm{dP}_{\mathrm{MAX}}$ (最大圧損值) を評価した。還

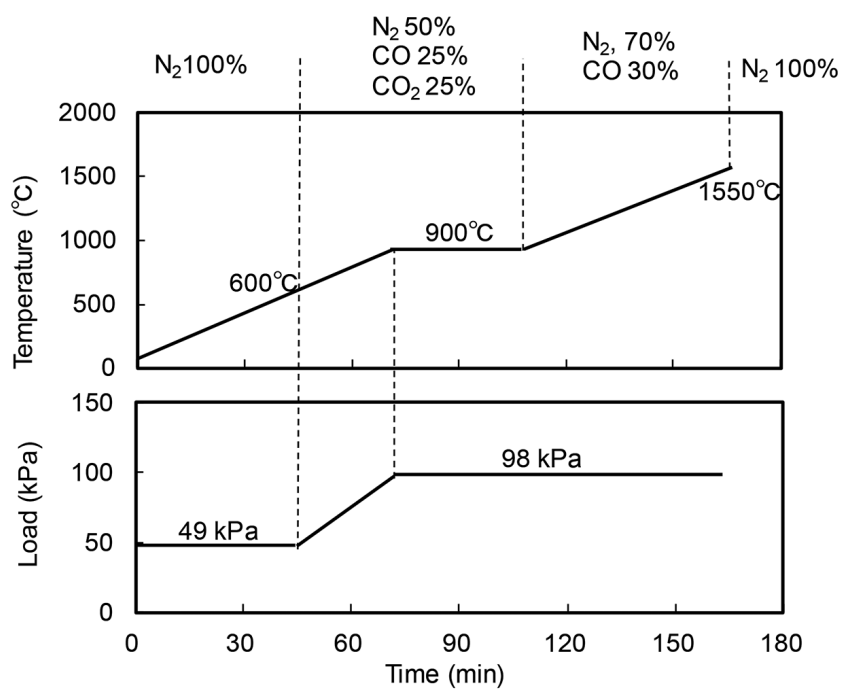

Fig. 1. Experimental conditions of the softening-melting test.
元過程での液相率の変化を, FactSage（ver. 6.4）を用いて 算出した。その際に, 還元前の成分と, 荷重軟化試験で実 測された還元率から, 温度毎の鉱石層の成分 $\left(\left(\mathrm{CaO}, \mathrm{SiO}_{2}\right.\right.$, $\left.\mathrm{Al}_{2} \mathrm{O}_{3}, \mathrm{MgO}, \mathrm{Fe}_{2} \mathrm{O}_{3}, \mathrm{FeO}, \mathrm{Fe}\right)$ を算出した。

\section{3．試験結果と考察}

\section{$3 \cdot 1 \quad$ 還元前の装入物の特性}

Table 1 に, 本研究で使用した装入物の化学成分と気孔 率，打よび各バスケットの化学成分を示す。2種のペレッ 卜は，いずれも焼結鉱と比べて低い全気孔率を示したが， $200 \mu \mathrm{m}$ 以下の気孔量と, $2 \mathrm{~mm}$ 以下の水法気孔率は, む しろ，ともに高かった。オリビンペレットの方が，LFぺ レットよりも僅かに気孔率が高く, 微細な気孔が多かった (Fig.2)。

Fig.3に, LFペレットとオリビンペレットの中心部の還 元前の組織を示す。いずれのペレットも, 焼結鉱よりもや や多孔質かつ, 均質な組織構造を呈していた。オリビンペ レットはLFペレットと比べて, 1)へマタイト粒子が細か い，2） $1200^{\circ} \mathrm{C}$ 付近での焼成中に，低粘度の融液が生成した 事を示す, 球形の気孔が多い，3）未涬化のオリビン粒子が 点在する ${ }^{15)}$ ，の特徴があった。

\section{$3 \cdot 2$ EBFから回収された試料の解析}

$3 \cdot 2 \cdot 1$ 回収試料の状態

Fig.4に，回収されたバスケットの高炉の高さ方向の位

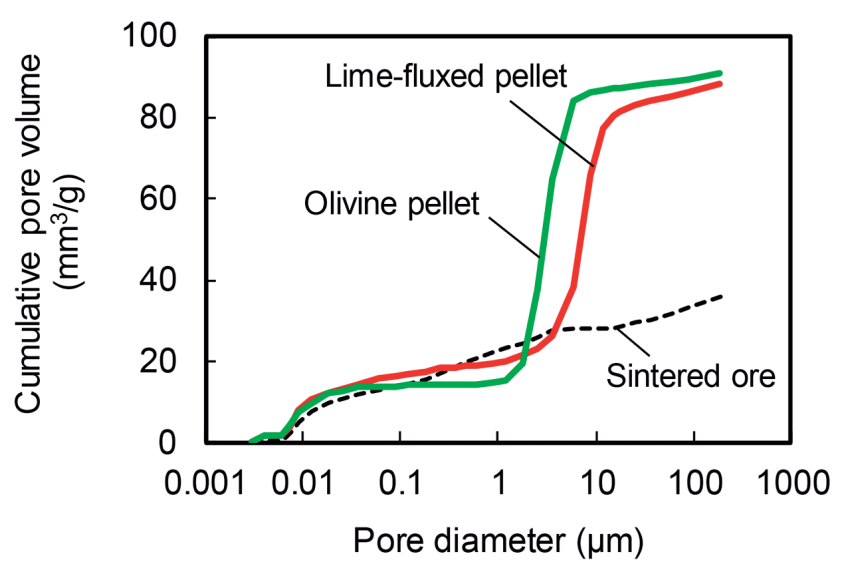

Fig. 2. Pore size distributions of burden materials used in this study. (Online version in color.)

Table 1. Chemical compositions and porosities of burden materials used in this study.

\begin{tabular}{|c|c|c|c|c|c|c|c|c|c|c|c|c|}
\hline & $\begin{array}{l}\text { T.Fe } \\
\mathrm{Wt} \%\end{array}$ & $\begin{array}{l}\mathrm{FeO} \\
\mathrm{Wt} \%\end{array}$ & $\begin{array}{l}\mathrm{CaO} \\
\mathrm{Wt} \%\end{array}$ & $\begin{array}{l}\mathrm{SiO}_{2} \\
\mathrm{Wt} \% \\
\end{array}$ & $\begin{array}{l}\mathrm{Al}_{2} \mathrm{O}_{3} \\
\mathrm{Wt} \%\end{array}$ & $\begin{array}{l}\mathrm{MgO} \\
\mathrm{Wt} \%\end{array}$ & $\begin{array}{c}\mathrm{CaO} / \mathrm{SiO}_{2} \\
-\end{array}$ & $\begin{array}{c}\mathrm{MgO} / \mathrm{SiO}_{2} \\
-\end{array}$ & $\begin{array}{c}<200 \mu \mathrm{m} \\
\text { Pore volume } \\
\mathrm{mm}^{3} / \mathrm{g}\end{array}$ & $\begin{array}{c}<2 \mathrm{~mm} \\
\text { Porosity } \\
\%\end{array}$ & $\begin{array}{c}\text { Total } \\
\text { Porosity } \\
\%\end{array}$ & $\begin{array}{c}\text { True } \\
\text { density } \\
\mathrm{g} / \mathrm{cm}^{3}\end{array}$ \\
\hline Sintered ore & 58.33 & 6.45 & 8.94 & 5.14 & 1.44 & 0.82 & 1.75 & 0.16 & 35.7 & 17.0 & 29.7 & 4.30 \\
\hline Lime-fluxed pellet & 65.72 & 0.93 & 2.54 & 2.17 & 0.58 & 0.04 & 1.17 & 0.02 & 88.6 & 21.0 & 26.1 & 4.81 \\
\hline Olivine pellet & 66.72 & 0.74 & 0.48 & 1.90 & 0.29 & 1.53 & 0.25 & 0.80 & 91.0 & 22.6 & 27.5 & 4.75 \\
\hline $50 \%$ sinter $+50 \%$ LF pellet & 62.03 & 3.69 & 5.74 & 3.66 & 1.01 & 0.43 & 1.46 & 0.09 & - & - & - & - \\
\hline
\end{tabular}


置を示す。全てのバスケットが回収され, 最上層からの層 数で試料名を付与した。13-2のみ, 比較的高炉の中心付近 (距離 $0.2 \mathrm{~m}$ ) に位置して打り, その他のバスケットは中間 部，あるいは周辺部で回収された。EBFでは，コークス中 心装入を実施して打り, 解体調査でも中心コークス層が観 察された。よって，13-2 は他のバスケットよりも高温条件 であったと推定される。全てのバスケットセットの端部間 の高さの差異は $89 \mathrm{~mm}$ 以下であり, 高さの差異の影響は比 較的小さい。Fig.5に, バスケットから回収された融着物の 割合を示す。13-2で融着物が多かったが，これは中心部に 位置していた影響である。中間部, 周辺部に打ける EBFの 融着帯は，第13層から第18層の間に位置していたと考え られる。な报，融着物の割合をバスケット B と Cで比較す ると, その多少は13-2層, 第18層, 第23層で異なっており, 同一の傾向は見られなかった。これは, 採取位置 (温度)の 影響がある事と, 試料量が少なく評価精度が小さい事, が 原因と推定される。

\section{$3 \cdot 2 \cdot 2$ 低温域での塊状物}

Fig.6に, 第 5 層, 第7層 (EBFの塊状帯) での塊状物の $<$ $10 \mathrm{~mm}$ 割合 (a) と, 圧壊強度 (b) を示す。バスケット $\mathrm{A} の$ $<10 \mathrm{~mm}$ 割合は, バスケット $\mathrm{B}, \mathrm{C} に$ 比べて常に高かった。 さらに, 同一七ットで比較すると, バスケット $\mathrm{B} の$ 方が, バスケット Cよりも<10 mm 割合が高かった。同様に, 圧 壊強度も, オリビンペレットが最も高く, 次いでLFペレッ 卜，焼結鉱の順であった。これらの結果から，塊状帯での
還元粉化量は高い順に, 焼結鉱 $>$ LFペレット>オリビン ペレットであった。

Fig.7 に, 塊状物の還元率 (a) と, 還元率 $65 \%$ 以下の試料 の $<10 \mu \mathrm{m}$ 気孔量 （b）を示す。第5層と第7層の試料の還 元率は, いずれも約 $30 \%$ でったので, このゾーンは EBF の熱保存帯である。よって，<10 $\mu \mathrm{m}$ 気孔量に差異があっ ても，ほぼ同一の還元率であったと考えられる。13-2は，

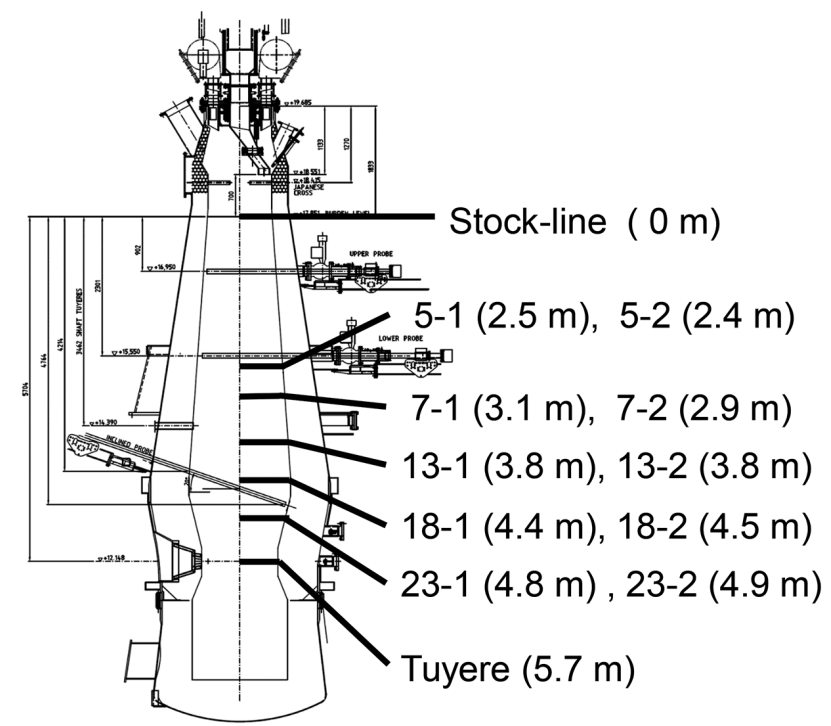

Fig. 4. Locations of excavated baskets in the vertical direction of the EBF. Numerical values denote the average depth of basket sets from the stock-line.

\section{Lime-fluxed pellets}

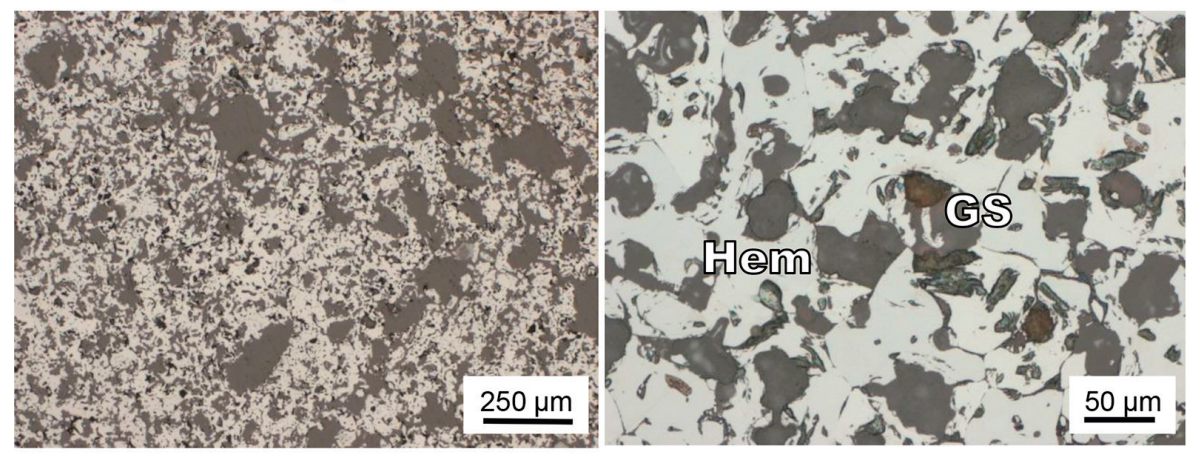

\section{Olivine pellets}
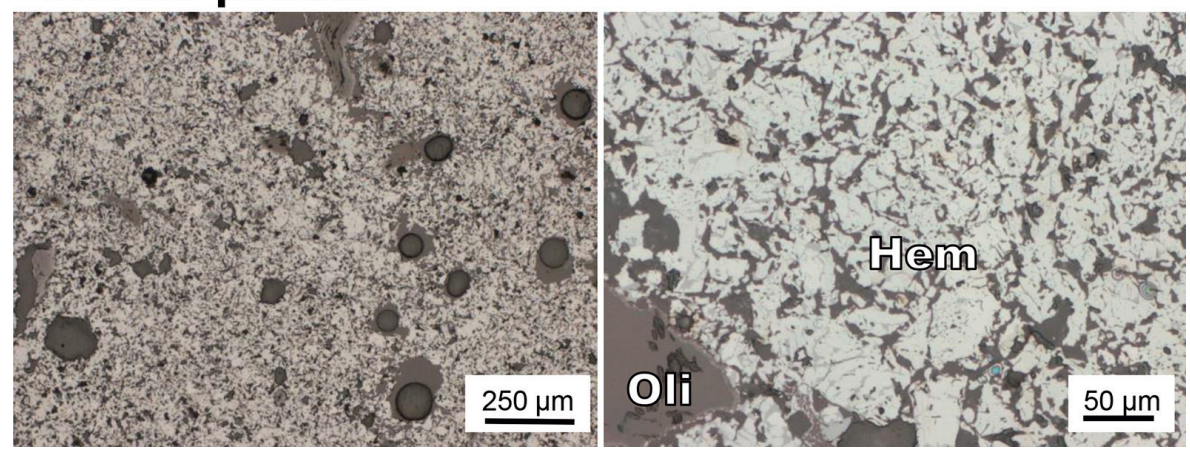

Fig. 3. Microstructures of the cores of lime-fluxed pellets and olivine pellets before reduction. (Magnification $\times 50$ (left), $\times 200$ (right)) Hem: hematite, GS: glassy silicate, Oli: relict olivine. (Online version in color.) 
中心付近にあり，高還元率を呈した。第18層と第23層で特 に観察された，同条件のバスケット試料間の大きな還元率 の差異も，同様に回収位置の差異によるものである。全て の領域で, LFペレットとオリビンペレットの還元率の差 異は僅かであった。還元前 (Fig.3) と同様に, 焼結鉱の $<$ $10 \mu \mathrm{m}$ 気孔量は, 常にペレットよりも少なかった。第13層 までは, オリビンペレットの $<10 \mu \mathrm{m}$ 気孔量は, LFペレッ トよりも高かったが, 第18，23層では低下した。

\section{$3 \cdot 2 \cdot 3$ 高温域での融着物}

Fig.8に, 第18層で回収された融着物の外観写真を示す。

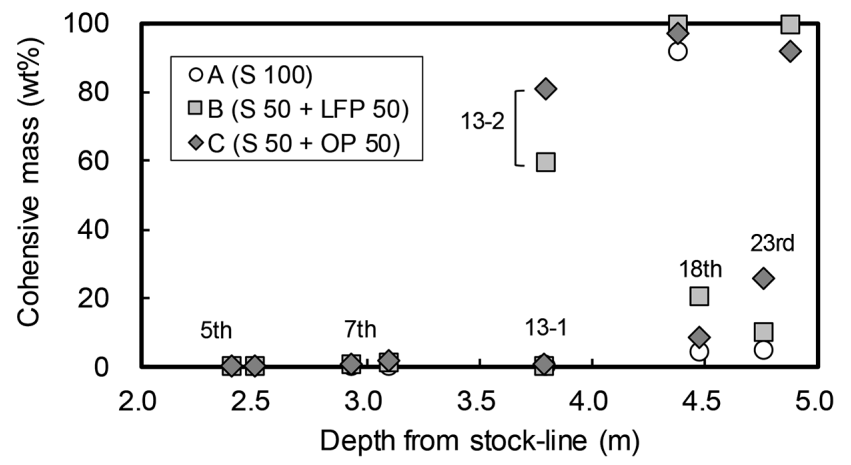

Fig. 5. Changes in the cohesive mass ratios of excavated backset samples with depth from the stock-line of the EBF.
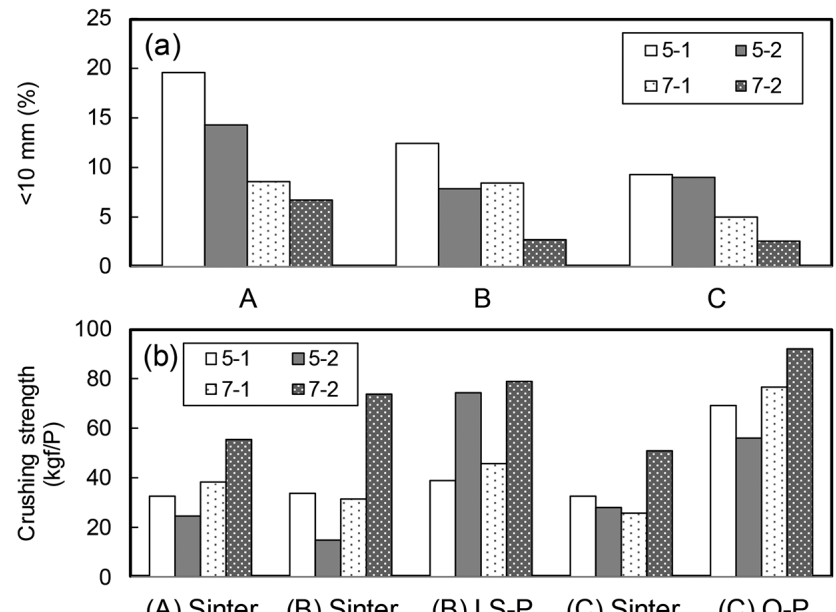

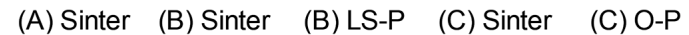

Fig. 6. The $<10 \mathrm{~mm}$ fraction (a) and crushing strength (b) of samples in the lumpy zone in the EBF.

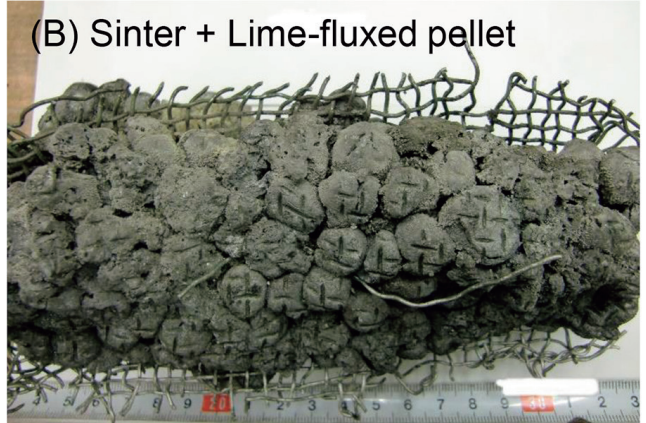

(C) Sinter + Olivine pellet

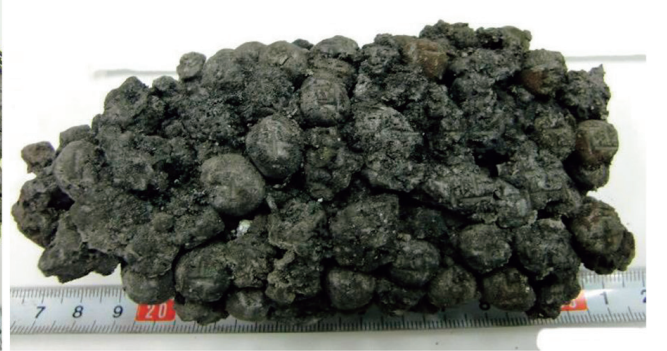

Fig. 8. Cohesive masses found in the18th layer. (Online version in color.)
Fig.9に, 第18層と第23層で観察された融着物のマクロ組 織を示す。併せて, 融着物の還元率の測定結果も示す。第 18 層では, バスケット $\mathrm{B} の$ 方が, バスケット Cよりも粒子 間距離が短く, 融着が進行していた。さらに18-1-Bのバス ケットの中 (LFペレット) と外 ( $100 \%$ オリビンペレット) を直接比較すると, LFペレットの方が融着が進行してい る傾向があった。同様に, 第23層のバスケット Bの中と外 を直接比較すると, いずれのペレットも融着が進行し, ウ スタイト核の一部の流出が観察されるものの, バスケット の中の方がより融着が進行しており, 特にLFペレットの 荷重による潰れが顕著であった。このLFペレットとオリ ビンペレットの融着挙動の差異については, 3·3節と $3 \cdot 4$ 節にて検証, 考察する。Kaushik and Fruehan $\left.{ }^{6}\right)$ は, 80\%に予 備還元したオリビンペレットの $\mathrm{N}_{2}$ 中の昇温過程で，アル

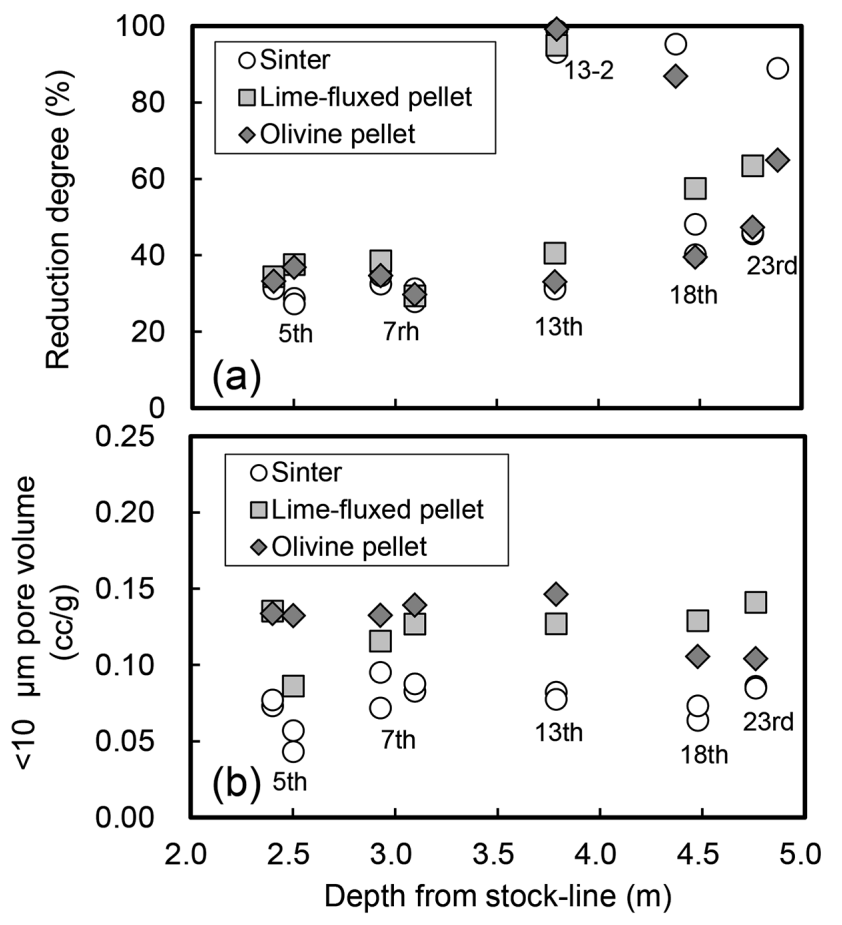

Fig. 7. Reduction degree (a) and $<10 \mu \mathrm{m}$ pore volume (b) of 'lumpy' sintered ores, lime-fluxed pellets and olivine pellets as a function of the depth from the stock-line. Pore volumes of samples with reduction degree below 65 $\%$ are shown. 
カリによる低温でのスラグ浸出を観察している。本研究で は，還元率が $65 \%$ までと低かったために，オリビンペレッ トのウスタイトコアの流出は観察されなかった。

Fig.10に, 第18層の近接した位置 (Fig.9中A図) に存在 していた装入物のミクロ組織を示す。ペレットは, 焼結鉱 に比べて粒子内部まで還元が進行していた。LFペレット は，表層のメタル層が多孔質であり，還元が中心部まで進 行していたものの, 中心部には島状の未還元ウスタイト相 が観察された。対してオリビンペレットは，表層に微細で 緻密なメタル層を形成し, 内部は酸化鉄層が存在し，より トポケミカルな還元様式を呈していた。Fig.7 (b) で観察さ れた，オリビンペレット中の $<10 \mu \mathrm{m}$ 気孔量の低下は，こ の酸化鉄層の緻密化によるものと推定される。このような 還元後組織の差異は，還元前の気孔構造 (Fig.2) と，へマ タイト粒子径 (Fig.3) の差違に起因し,より高温域での融 着挙動にも影響を与えると推定される。特に, メタルシェ ルの物理的な性状の差異は，コアからのスラグ浸出挙動に も大きな影響を与えると考えられる ${ }^{6}$ 。

$3 \cdot 2 \cdot 4$ 焼結鉱とペレットの界面

Fig.11に，13-2の焼結鉱とペレットの界面の組織を示す。 バスケット $\mathrm{B}, \mathrm{C}$ は，中心部付近に存在していたため，これ らの還元率はそれぞれ，98.4\%，98.8\%と，高かった。LFぺ レットと焼結鉱の界面には，スラグが生成していたのに対 して，オリビンペレットと焼結鉱の界面のスラグ量は少 なった。Goldring $5^{16)}$ も，実機高炉の $\mathrm{N}_{2}$ 冷却による解体調 査で, $\mathrm{LF}$ ペレット $(\mathrm{C} / \mathrm{S} ; 0.7, \mathrm{MgO} ; 0.3 \mathrm{wt} \%)$ と焼結鉱 $(\mathrm{C} / \mathrm{S}$; 1.6, $\mathrm{MgO} ; 1.6 \mathrm{wt} \%)$ の界面で含 $\mathrm{FeO}$ スラグの形成を観察し
ている。

Chaigneau $ら^{9)}$ は，高塩基度焼結鉱とオリビンペレットの 混合使用による，高温性状改善の相乗効果を報告している が，その機構のひとつとして，このような異種界面での浸 出スラグの混合によるスラグ性状変化が考えられる。

Nogueira and Fruehan ${ }^{7)}$ は, 酸性ペレットの高い収縮性が, ドロマイトペレットとの混合により改善される事を観察 し，その原因を浸出スラグの粘度上昇としている。さらに， Kaushik and Fruehan $\left.{ }^{6}\right)$ は, 2 種のペレットの混合時の溶融段 階を，1）固相メタルの焼結，2）融液の初期生成，3）浸出 スラグの同化，4）コアの同化と纏め, 浸出スラグ同化の因

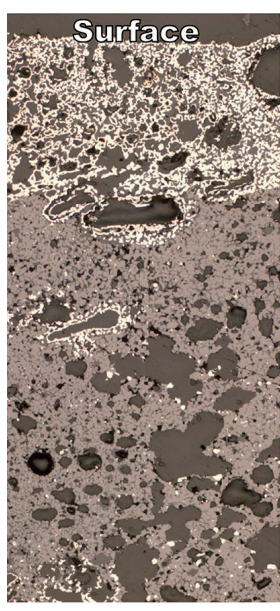

Sinter

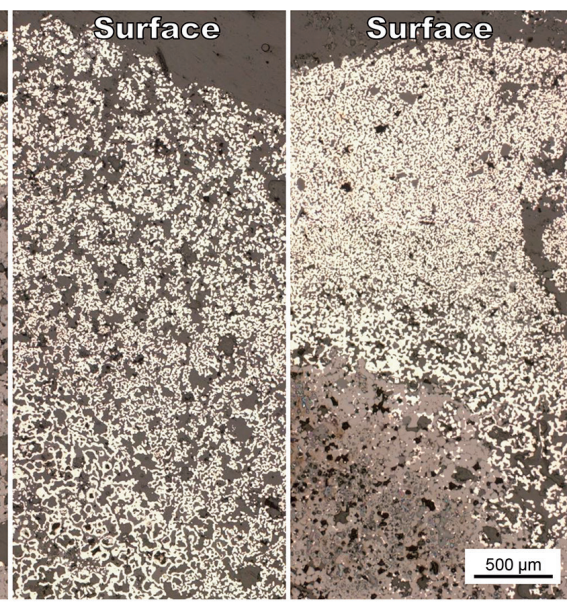

Lime-fluxed pellet
Olivine pellet
Fig. 10. Differences in reduction behaviors among the burden materials in area A of Fig.9 in the 18th layer. (Online version in color.)

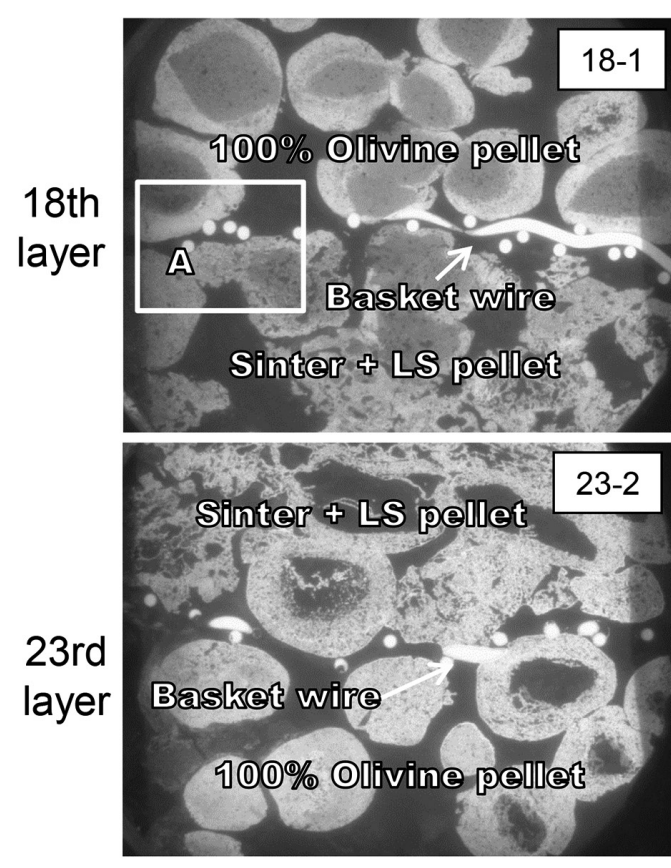

(B) Sinter + LS pellet
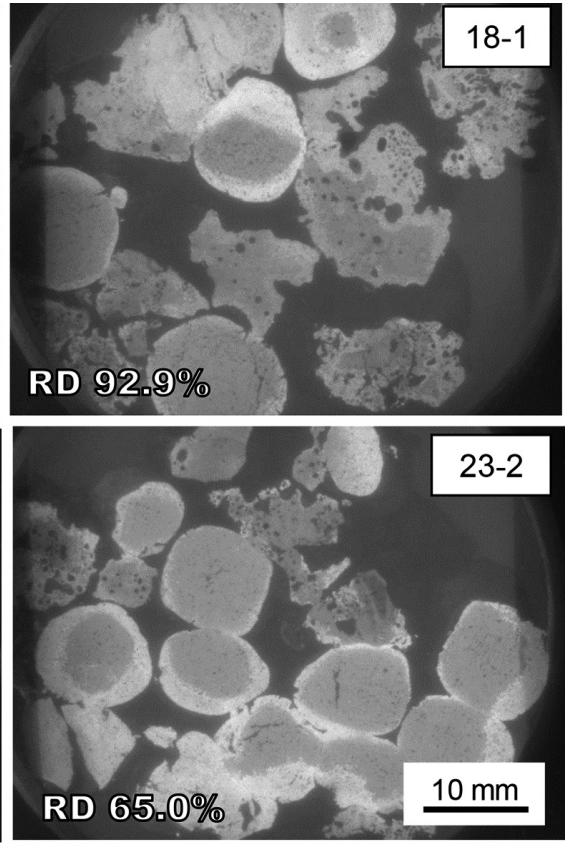

(C) Sinter + Olivine pellet

Fig. 9. Macro photos of cohesive materials found in the 18th and 23rd layers. RD denotes the reduction degree. A is closely observed in Fig.10. 
子を，メタルシェルの構造と融液粘度としている。本研究 でも，焼結鉱とペレットの界面において (Fig.11)，メタル 相の存在が観察されたので，この界面での同化現象は，ぺ レットのメタルシェルを介した融液の浸出，同化が関連す るものと考えられる。

\section{$3 \cdot 3$ 荷重軟化試験での融着挙動}

Fig.12に,バスケット A, B, C と同一試料条件の荷重軟化 試験結果を示す。高温性状の特性值を Table 2 に纒めた。単 味評価では，オリビンペレットの $\mathrm{T}_{\mathrm{S}}$ は, LFペレットよりも 高く，既報の結果と一致した ${ }^{11)}$ 。焼結鉱へのペレット混合 によって， $\mathrm{T}_{\mathrm{S}}$ の上昇と $\mathrm{T}_{\mathrm{E}}, \mathrm{T}_{\mathrm{D}}$ の低下が見られ，この結果に より dTが低下した。S 值，最大圧損值は，ともに低下した。 これらの改善効果は，オリビンペレット使用時に大きかっ た。圧損が上昇するまでのガス還元は，LFペレット混合時 とオリビンペレット混合時で差異はなかったが，圧損上昇 後の溶融還元は，LFペレット混合時の方が急速に進行し た。 $\mathrm{dP}_{\mathrm{MAX}}$ は, $1200^{\circ} \mathrm{C}$ 以上での液相率と鉱石層の空隙構造 に依存する。液相率は，化学成分と還元率で決定される。 異種原料混合による空陌の増加は僅か ${ }^{8)}$ であるので, 焼結 鉱とオリビンペレットの混合時の低い $\mathrm{dP}_{\mathrm{MAX}}$ は, 低脈石量 が主要な要因である。

Fig. 13 に $1300^{\circ} \mathrm{C}$ 中断試料の比較を示す。単味打よび焼 結鉱との混合時でも，LFペレットは，メタルシェルを残し て, コア部のスラグとウスタイトが浸み出した結果, 空洞 となっていた。これに対して，オリビンペレットは，コア 部のウスタイト相が未溶融で残存していた。

\section{$3 \cdot 4$ 焼結鉱との混合時のペレットの融着挙動}

Fig.14に, Table 2 に示す各水準の, 液相率の温度変化の

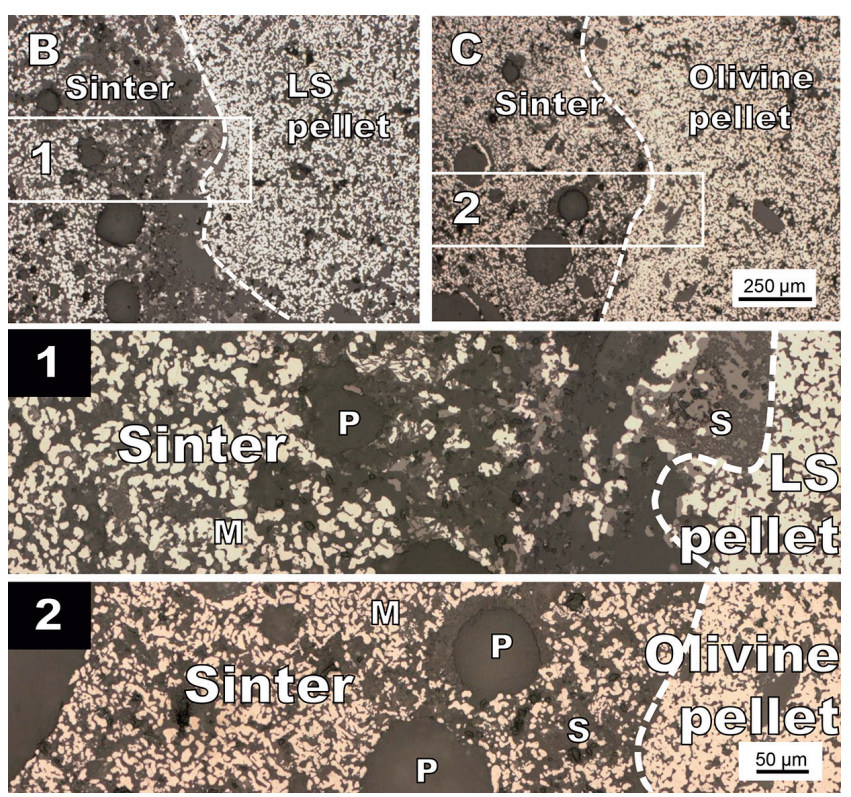

Fig. 11. Interface between sintered ores and lime-fluxed pellets (B) and between sintered ores and olivine pellets (C) in the 13th layer. M: metal, S: slag, P: pore. (Online version in color.)
計算值を示す。Fig.9-11の観察結果から, 焼結鉱との混 合使用に打いては, 低温域では個々の装入物の挙動に依存 し, 高温になるに従って, 焼結鉱との完全混合後の挙動に 近づく ${ }^{8)}$, と仮定した。融液生成温度は，オリビンペレット $<\mathrm{LF}$ ペレット<焼結鉱の順に低く, 過去の測定結果とほ ぼ一致した ${ }^{17)}$ 。オリビンペレットで観察された，コア酸化 物の低温域での緻密化（Fig.7（b)，10）は，この低い溶融開 始温度が原因と推定される。しかし, その後の液相率の増

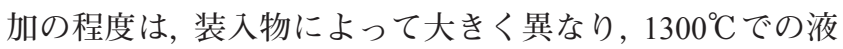
相率は，オリビンペレットが最も低かった。この挙動は, 既報でも報告されており ${ }^{2-4,15)}$, fayalite slag と共存ウスタイ トの融点上昇によるものである。いずれのペレットも, 焼 結鉱への混合により，高温での液相率を低下させ，特に才 リビンペレット使用時の低下が大きかった。1300 Cでの融

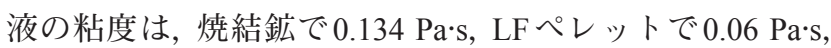
オリビンペレットで $0.04 \mathrm{~Pa} \cdot \mathrm{s}$ と評価された ${ }^{18)}$ 。よって, LF ペレット混合使用時は，多量の低粘度スラグが浸出すると 考えられる。この推察は，これまでの結果 (Fig.11-13) と 良く一致した。

Fig.15に, これまでに得られた結果から推定された，焼 結鉱とペレット混合時の還元過程での融着挙動を, 模式的 に示す。LFペレット混合時は, 焼結鉱から多量のスラグが 浸出するとともに, LFスラグからも多量のスラグが浸出

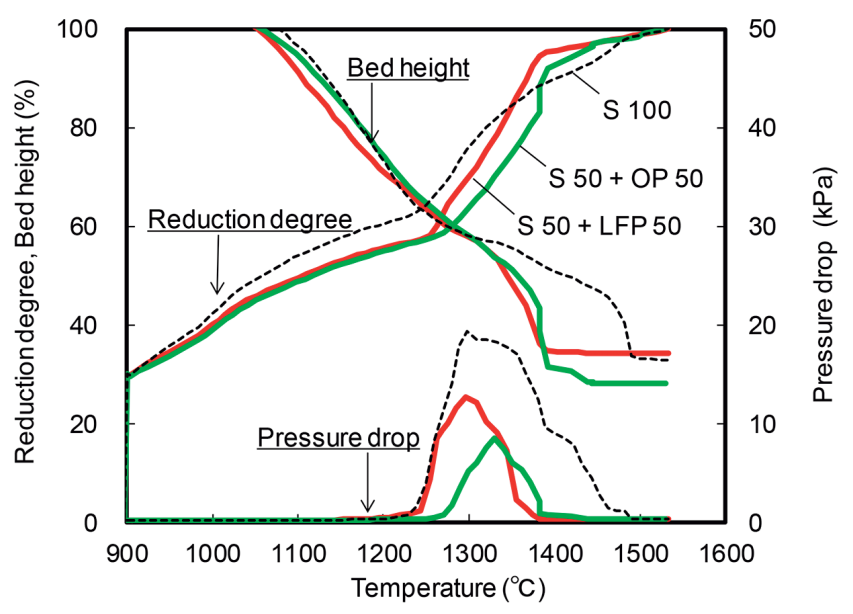

Fig. 12. Results of softening-melting tests. (Online version in color.)

Table 2. Specific values for evaluating reduction behaviors of burden materials in the softening-melting tests.

\begin{tabular}{|c|c|c|c|c|c|c|}
\hline & & Sinter & $\begin{array}{c}\text { LF } \\
\text { Pellet }\end{array}$ & $\begin{array}{c}\text { Olivine } \\
\text { pellet }\end{array}$ & $\begin{array}{c}\text { Sinter }+ \\
\text { LF Pellet }\end{array}$ & $\begin{array}{c}\text { Sinter }+ \\
\text { Olivine pellet }\end{array}$ \\
\hline $\mathrm{T}_{\mathrm{S}}$ & ${ }^{\circ} \mathrm{C}$ & 1238 & 1232 & 1320 & 1244 & 1280 \\
\hline $\mathrm{T}_{\mathrm{E}}$ & ${ }^{\circ} \mathrm{C}$ & 1482 & 1509 & 1356 & 1367 & 1382 \\
\hline $\mathrm{dT}$ & ${ }^{\circ} \mathrm{C}$ & 244 & 277 & 36 & 123 & 102 \\
\hline $\mathrm{T}_{50}$ & ${ }^{\circ} \mathrm{C}$ & 1411 & 1364 & 1335 & 1355 & 1362 \\
\hline $\mathrm{T}_{\mathrm{D}}$ & ${ }^{\circ} \mathrm{C}$ & 1487 & 1394 & 1355 & 1380 & 1383 \\
\hline $\mathrm{dP}_{\mathrm{MAX}}$ & $\mathrm{kPa}$ & 19.4 & 24.7 & 1.9 & 12.7 & 8.5 \\
\hline S-value & $\mathrm{kPa} \cdot \mathrm{min}$ & 236 & 322 & 2 & 88 & 47 \\
\hline
\end{tabular}



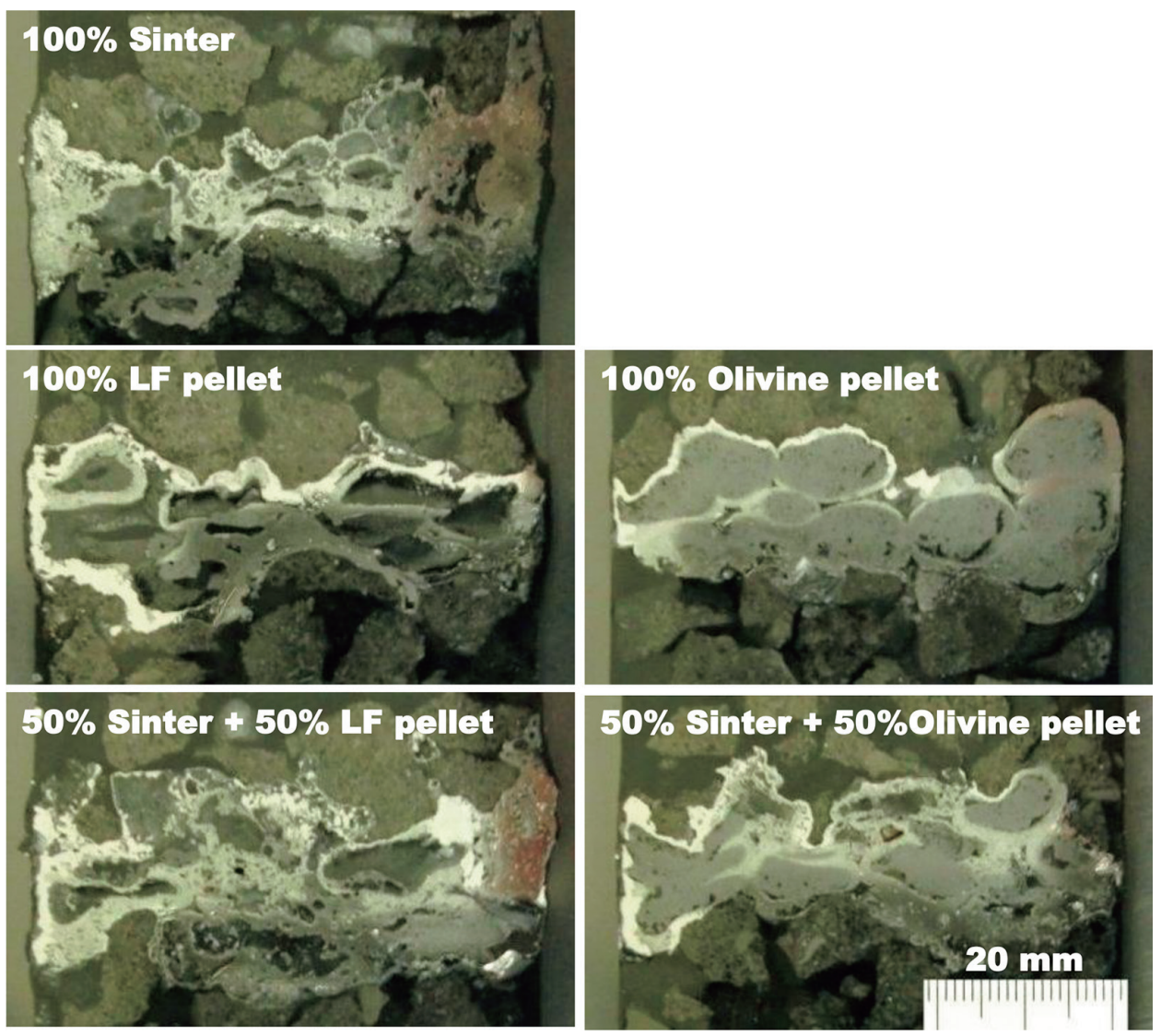

Fig. 13. Cross sections of samples quenched at $1300^{\circ} \mathrm{C}$ during the softening-melting tests. (Online version in color.)

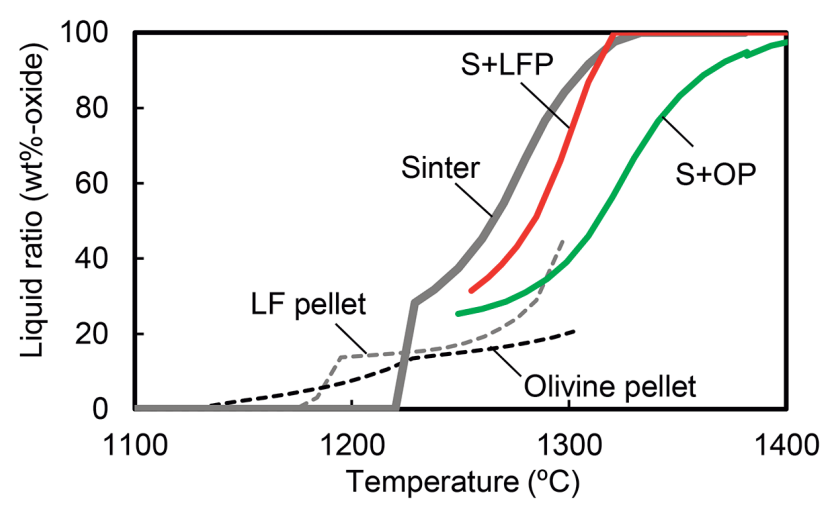

Fig. 14. Calculation results of the liquid ratio to sum of oxides for various burden conditions as a function of sample temperature. (Online version in color.)

する。LFペレットからの融液粘度は低く, 容易に多孔質な メタルシェルを通過できる。浸出スラグが同化した後も, 液相率は高い状態が維持される。一方で, オリビンペレッ 卜混合時は, オリビンペレットからは少量の低粘度スラグ が焼結鉱からの融液と同化する。その結果，液相率が低下 し，界面の融着が抑制される。塩基性焼結鉱 $50 \%$ とペレッ 卜を組み合わせた試験高炉での操業結果でも, オリビンペ レット $50 \%$ 使用時の方がオリビンペレットとLFペレット 併用時よりも安定したと報告されているが ${ }^{10)}$ ，その一因と して,このような融着挙動の差異が考えられる。

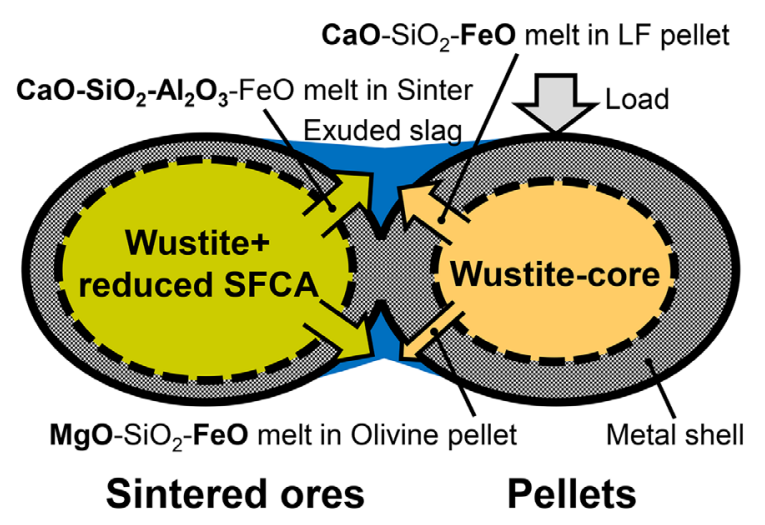

Fig. 15. Schematic explanation of the melting behavior of the mixed burden comprising with sintered ores and pellets during reduction (Online version in color.)

\section{4. 結言}

LKAB 社の EBFでバスケット評価試験を実施し, 低 $\mathrm{MgO}$ 焼結鉱, LFペレット，オリビンペレットからなる混合試料 の炉内融着挙動を解析した。以下の知見を得た。

(1) LFペレットとオリビンペレットは，ともに焼結鉱より も<200 $\mu \mathrm{m}$ 気孔が多かった。オリビンペレットは, 微 細な気孔が多く,へマタイト粒子が細かい特徵があり， 還元挙動へ影響を与えた。

（2）塊状帯では, 焼結鉱に比べてペレットの方が還元粉化 
量は低く, 特にオリビンペレットは小さかった。還元 中のオリビンペレットの $<10 \mu \mathrm{m}$ 気孔量は, LFペレッ トよりも高かったが, 高温域では酸化物コアの緻密化 に伴って減少した。

（3）融着帯では，オリビンペレットよりも LFペレットの方 が融着が進行した。LFペレットは, 焼結鉱との界面で スラグを多量に生成した。一方で，オリビンペレット の焼結鉱との界面でのスラグ量は少なかった。荷重軟 化試験でも，オリビンペレットと焼結鉱との混合によ り，高温性状が大きく改善された。

（4）オリビンペレットは, 還元過程での初期融液生成温度 は低いものの, その後の高温域での液相率の増加は小 さく, 低 $\mathrm{MgO}$ 焼結鉱との混合において, 浸出スラグの 量が低減した。

\section{文献}

1 ) K.Higuchi, Y.Takamoto, T.Orimoto, T.Sato, F.Koizumi, K.Shinagawa and H.Furuta: Nippon Steel Tech. Rep., 94(2006), 36.

2 ) T.Borinder and X.Bi: Scand. J. Metall., 18(1989), 280.

3 ) A.Kemppainen, K.-i.Ohno, M.Iljana, O.Mattila, T.Paananen, E.-P. Heikkinen, T.Maeda, K.Kunitomo and T.Fabritius: ISIJ Int., 55(2015), 2039. https://doi.org/10.2355/isijinternational.ISIJINT-2015-023

4 ) M.Iljana, A.Kemppainen, T.Paananen, O.Mattila, E.-P.Heikkinen and T.Fabritius: ISIJ Int., 56(2016), 1705. https://doi.org/10.2355/ isijinternational.ISIJINT-2016-117
5 ) Y.Matsui, A.Sato, T.Oyama, T.Matsuo, S.Kitayama and R.Ono: ISIJ Int., 43(2003), 166. https://doi.org/10.2355/isijinternational.43.166

6 ) P.Kaushik and R.J.Fruehan: Ironmaking Steelmaking, 34(2007), 10. https://doi.org/10.1179/174328106X118161

7 ) P.F.Nogueira and R.J.Fruehan: Metall. Mater. Trans. B., 36(2005), 583. https://doi.org/10.1007/s11663-005-0049-5

8 ) X.Liu, T.Honeyands, D.O'Dea, B.Ellis and G.Evans: Proc. 8th Int. Congr. on the Science and Technology of Ironmaking (ICSTI), ASMET, Leoben, (2018), ID: 128.

9 ) R.Chaigneau, T.Bakker, A.Steeghs and R.Bergstrand: 60th Ironmaking Conf. Proc., ISS, Warrendale, PA, (2001), 689.

10) L.Hooey, J.Sterneland and M.Hallin: 60th Ironmaking Conf. Proc., ISS, Warrendale, PA, (2001), 197.

11) M.Hallin: Proc. John Floyd Int. Symp. Sustainable Development in Metals Processing, AusIMM, Carlton, VIC, (2005), 9.

12) M.Hallin: Proc. Int. Blast Furnace Lower Zone Symp., AusIMM, Carlton, VIC, (2002), 22-1.

13) S.Kasama, T.Haga, T.Inazumi and K.Sato: Tetsu-to-Hagané, 83(1997), 109 (in Japanese). https://doi.org/10.2355/tetsutohagane1955.83.2_109

14) K.Higuchi, S.Matsuzaki, K.Saito and S.Nomura: ISIJ Int., 60(2020), 2218. https://doi.org/10.2355/isijinternational.ISIJINT-2020-063

15) P.Semberg, C.Andersson and B.Björkman: ISIJ Int., 53(2013), 1341. https://doi.org/10.2355/isijinternational.53.1341

16) D.C.Goldring, J.A.Jones and K.Grebe: Ironmaking Steelmaking, 24(1997), 373

17) I.Shigaki, S.Shirouchi, K.Tokutake and N.Hasegawa: ISIJ Int., 30(1990), 199. https://doi.org/10.2355/isijinternational.30.199

18) T.Iida, H.Sakai, Y.Kita and K.Murakami: High Temp. Mater. Process., 19(2000), 153. https://doi.org/10.1515/HTMP.2000.19.3-4.153 